\title{
PERKEMBANGAN ANAK PADA TOKOH MONA DAN LISA DALAM KKPK MONALISA KARYA ALYA : TEORI PSIKOLOGI SASTRA
}

\author{
Neva Atika Sari \\ Universitas Negeri Surabaya \\ Email: neva.atika@gmail.com
}

\begin{abstract}
Abstrak
Tokoh Mona dan Lisa mempunyai kepribadian yang berbeda, hal itu diakibabkan oleh didikan yang berbeda. Pada masa anak mereka lebih mementingkan pelajaran dan ego mereka tampak dalam ekstrakulikuler basket. Masa perkembangan anak-anak belajar untuk memperoleh kesenangan dan kepuasan dari menyelesaikan tugas khususnya tugas akademik sehingga membuat anak-anak bangga terhadap prestasi yang didapatkannya, Perkembangan seorang anak sangat berbeda bergantung dari didikan dari orangtua. Hal tersebut, dapat dilihat pada perkembangan Tokoh Mona dan Lisa yang ada dalam Kecil-Kecil Punya Karya (KKPK) yang berjudul Monalisa. Metode yang digunakan yakni deskriptif analisis. Teknik pengumpulan data, dilakukan dengan langkah pembacaan KKPK Monalisa Karya Ayla dari awal hingga ahir secara berulang-ulang, Memberi tanda pada halaman KKPK "Monalisa", Mengetik semua data yang ada dalam KKPK "Monalisa" sesuai dengan kajian psikologi sastra, lebih mengarah pada perkembangan anak-anak yang diterapkan oleh Norman H. Erikson.
\end{abstract}

Kata kunci : sastra anak, KKPK, psikologi sastra.

\begin{abstract}
The character of Mona and Lisa have different personalities, it is caused by a different upbringing. At the time of their child more interested in learning and ego they appear in extracurricular basketball. Future development of the children learn to get pleasure and satisfaction of completing a task, especially academic assignments that make children proud of the achievements gained, development of a child is very different depending on the education of the parents. It can be seen in the characters development and the Mona Lisa is in the Small Small-Have Work (KKPK) entitled Monalisa. The method used the descriptive analysis. Data collection techniques, carried out by step reading of KKPK Monalisa work Ayla from beginning to ahir repeatedly, Marking the page KKPK "Monalisa", Typing
\end{abstract}


all the existing data in KKPK "Monalisa" according to the study of psychology literature, it leads to the development children adopted by Norman H. Erikson.

Keywords: children literature, KKPK, psycology of literature.

\section{PENDAHULUAN}

Sastra anak adalah sastra yang berbicara tentang apa saja yang menyangkut masalah kehidupan ini sehingga mampu memberikan informasi dan pemahaman yang lebih baik tentang kehidupan itu sendiri kepada anak. Sastra anak memiliki ciri berbeda dengan sastra umum yang mengedepankan aspek lingkup sosial, agama, dan identitas (Rokib, 2015; 2016). Akan adanya sastra anak maka orang dewasa dapat memberikan pengetahuan kepada anak-anak apa yang harus diperbuat anak sesuai dengan usia anak, adanya sastra anak juga dapat digunakan sebagai alat untuk memperkembangkan budi pekerti manusia, budi pekerti perlu ditanam sejak usia dini sehingga budi peerti dapat berjalan hingga usia dewasa. Budi pekerti menurut Sugihastuti dalam uharwanto (2001: 252) yakni alat batin yang termasuk panduan akal dan perasaan untuk menimbang baik dan buruk. Muatan budi pekerti dalam sastra anak maksudnya yakni identifikasi budi pekerti yang dapat dikandung oleh sejumlah unsur dalam karya sastra anak.

Feist dan Feist $(2008,215-217)$ menyatakan bahwa perwujudan dinamika kepribadian adalah hasil interaksi antara kebutuhan biologis yang 
mendasar dan pengungkapannya melalui tindakan-tindakan sosial. Hal ini dapat dikatakan bahwa perkembangan kehidupan individu dari bayi hingga dewasa umumnya dipengaruhi oleh hasil interaksi sosial dengan individu lainnya sehingga membuat individu menjadi matang baik secara fisik maupun secara psikologis. Erikson (Alwisol, 2009:87) menyatakan bahwa ego adalah sumber kesadaran diri indvidu. Ego mengembangkan perasaan yang berkelanjutan diri antara masa lalu dengan masa yang akan datang selama proses penyesuaian diri dengan realita.

Friedman dan Schustack $(2006,156)$ mengemukakan bahwa ego berkembang mengikuti tahap epigenik, artinya tiap bagian dari ego berkembang pada tahap perkembangan tertentu dalam rentang waktu tertentu. Menurutnya, semua yag berkembang mempunyai rencana dasar, dan dari perencanaan ini muncul bagian-bagian, masing-masing bagian mempunya waktu khusus untuk menjadi pusat perkembangan, sampai semua bagian muncul untuk membentuk keseluruhan fungsi.

Masa perkembangan kerajinan dan Inferioritas, anak-anak belajar untuk memperoleh kesenangan dan kepuasan dari menyelesaikan tugas khususnya terutama tugas akademik. Penyelesaian yang sukses pada tahapan ini akan menciptakan anak yang dapat memecahkan masalah dan bangga akan prestasi yang diperoleh. Keterampilan ego yang diperoleh adalah kompetensi. Di sisi lain, anak yang tidak mampu untuk menemukan solusi positif dan tidak mampu mencapai apa yang diraih teman-teman sebaya akan merasa inferior. Identitas ego dibentuk oleh konflik dan 
peristiwa masa lalu, masa kini, dan masa yang akan datang (Erikson dalam Alwisol, 2016: 98)

Pada psikologi Norman H Erikson, menjelaskan dalam perkembangan terdapat konflik antara positif dan negatif yang selalu ada sepanjang hayat namun karena hal itulah dapat membuat kepribadian menjadi hidup (Alwisol, 2016: 97).

Dari konsep pemikiran yang telah dipaparkan tersebut, maka masalah yang akan diteliti dalam penelitian meliputi bagaimana kepribadian anak pada Tokoh Mona dan Lisa dalam KKPK "Monalisa" Karya Ayla dan bagaimana perkembangan anak pada Tokoh Mona dan Lisa dalam KKPK “Monalisa” Karya Ayla.

Penelitian ini, secara teoritis untuk membantu (1) pengembangan ilmu sastra terutama dalam teori Psikologi Sastra yang lebih membahas mengenai perkembangan pada anak-anak. (2) memperoleh informasi mengenai manfaat sastra anak pada pembentukan kepribadian manusia yang dimulai dari usia anak-anak. (3) memperoleh informasi berbagai hal terkait dengan karya sastra anak yang berkarakter. (4) merumuskan temuan yang relevan yang berkaitan dengan sastra anak berbasis karakter untuk menghindari akan penyimpangan nilai-nilai kemanusiaan, terutama pada diri seorang anak.

Penelitian ini, secara praktis dapat digunakan sebagai (1) Acuan untuk membantu mengetahui psikologi pekembangan anak melalui KKPK. (2) memilih buku cerita yang baik untuk di baca anak-anak. (3) cerita anak 
yang baik dapat memberikan dampak kepada pembaca untuk memiliki rasa perduli terhadap orang lain.(4) cerita anak dapat membentuk karakter anak baik secara langsung ataupun tidak langsung karena sesuai dengan fungsi sastra yakni dapat menyenangkan dan berguna bagi pembaca.

\section{METODE}

Penelitian ini menggunakan metode deskriptif analisis yang dilakukan dengan cara mendeskripsikan fakta-fakta yang ada dalam data kemudian dilakukan analisis. Melalui metode deskriptif analisis, peneliti akan mendeskripsikan masalah-masalah yang terdapat dalam sastra anak KKPK, berjudul Monalisa Karya Alya yang berkaitan dengan Kepribadian dan perkembangan anak pada Tokoh Mona dan Lisa.

Pendekatan yang digunakan dalam penelitian kali ini, yakni pendekatan psikologis yang lebih mengarah kepada objektif karena datadata yang ada ditemukan dalam karya sastra anak yakni KKPK. Pendekatan tersebut, digunakan sesuai pendapat Nyoman (2015: 61) apabila pendekatan psikologis, perhatiannya lebih ditujukan pada pengarang maka model penelitiannya lebih dekat pendekatan ekspresif, sebaliknya, apabila perhatian ditujukan pada karya, maka model penelitiannya lebih dekat dengan endekatan objektif.

Sumber data yang digunakan dalam penelitian ini diambil dari KKPK yang berjudul Monalisa Karya Ayla. Diterbitkan oleh Mizan, Bandung sebagai cetakan pertama pada tahun 2016. Termasuk KKPK Gold Edition atau Bestseller. Berjumlah 133 halaman. 
Pengumpulan data dilakukan dengan teknik studi pustaka disertai dengan penjelasan yang sesuai dengan kajian Psikologi Kepribadian Norman. H. Erikson. Pengmpulan data dilakukan tahap sebagai berikut : 1). Melakukan pembacaan KKPK Monalisa Karya Ayla dari awal hingga ahir secara berulang-ulang sehingga dapat mengetahui mengenai peristiwa apa yang diungkapkan oleh pengarang dalam KKPK Monalisa sehingga dapat menemukan data yang sesuai dengan teori yang digunakan sesuai yang diungkapkan oleh "Ratna (2004: 18) menjelaskan bahwa membaca karya sastra perlu dilakukan secara berulang-ulang dengan tujuan agar keseluruhan unsur karya dapat dipahami secara maksimal". Pembacaan dilakukan secara berulang bertujuan untuk lebih memahami terhadap apa yang diungkpakan dalam suatu karya sastra. 2) Memberi tanda pada halaman KKPK "Monalisa" dengan cara menggarisbawahi untuk mendapatkan data sesuai dengan rumusan masalah penelitian. 3) Mengetik semua data yang ada dalam KKPK "Monalisa" sesuai dengan kajian psikologi sastra, lebih mengarah pada perkembangan anak-anak yang diterapkan oleh Norman H. Erikson.

Analisis data dilakukan sebagai berikut : 1) Mengelompokkan data yang ada dalam KKPK "Monalisa". 2) Menganalisis data yang sesuai dengan fokus penelitian. 3) Melanjutkan dengan membuat simpulan dari data yang telah dianalisis.

\section{PEMBAHASAN}

http://journal.unesa.ac.id/index.php/jpi ISSN: 22477-5150 | 193 
Usia Mona dan Lisa termasuk masa perkembangan kerajinan dan Inferioritas karena mereka berdua sudah bersekolah dan keluar dari dunia keluarga, perkembangan itu terdapat dalam prestasi akademik, hal itu dapat dilihat meski Mona mengikuti pertandingan basket namun Mona tetap menomorsatukan pelajaran sekolahnya begitupun dengan Lisa yang mendapatkan nilai-nilai yang bagus di sekolahnya. Akan adanya prestasi akademik yang teta dipertahankan oleh mereka berdua, Mona tidak ketinggalan dalam pelajaran meski harus mengikuti latihan lomba basket dan Lisa yang mendapatkan nilai-nilai bagus bisa mendapatkan hadiah dari Dad untuk bertemu dengan saudara kembarnya dan tinggal sementara untuk liburan di rumah Mom yang sudah lama diinginkannya. Bukti kutipan sebagai berikut:

Hari ini adalah waktunya mendaftaran diri pada acara Fresh and Child Day. Dari jam pelajaran pertama semua murid sudah tidak sabar untuk menentukan pilihan mereka. Bahkan, saking semangatnya sampai-sampai ada anak yang tidak memerhatikan pelajaran karena keasyian melamun. Hati Monajuga berdebar-debar untuk menentukan pilihannya, tetapi dia tetap menomorsatukan pelajaran (Alya, 2016: 16).

Sebentar lagi waktunya liburan semester. Aku memutuskan untuk pergi ke rumahmu dan Mom di Santa Barbara. Itu hadiah dari Dad karena belakangan ini nilai-nilaiku bagus semua (Alya, 2016: 25).

Keterampilan ego yang diperoleh adalah kompetensi yakni akan komepetensi dalam memenagkan lomba basket. Ego yang diperoleh dipengaruhi dari pengalaman masa lalu, sekarang dan masa yang akan 
datang. Permasalahan masa lalu terjadi ketika Mona dan Lisa yang harus berpisah dan mereka berdua berharap bisa bertemu kembali dan Mona ingin memberikan hal yang terbaik untuk saudara kembarnya yakni bahwa Mona mengikuti lomba basket sesuai dengan olehraga yang dgemari oleh Lisa meski awalnya Mona waktu kecil lebih suka bermain boneka dan tidak begitu bisa dalam olahraga bola basket. Konflik saat ini yakni ketika Mona berhasil mengkuti lomba basket namun ada dua temannya yakni Tivanna dan Lolyta yang selalu menantang Mona dan tidak terima Mona menjadi pemimpin dalam perlombaan bola basket, Mona tidak pernah membalas perlakuan kedua temannya tersebut pada ahirnya kedua temannya meminta maaf kepada Mona dan mereka bersahabat, atas dukungan dan semangat untuk dipersembahkan kepada Lisa, Mona pun berhasil memenagkan pertandingan basket. Dari perlombaan basket itu Mona bisa merasa senang mendapatkan dukungan langsung dari saudara kembarnya. Keberhasilan itu pula termasuk salah satu langkah bisa mempersatukan keluarganya. Buktik kutipan sebagai berikut:

Demi Lisa yang mencintai basket, aku akan mendaftarkan diriku menjadi anggota klub basket untuk acara Fresh and Fit Chil Day. Aku akan membuktikan bahwa aku bisa memenangkan perlombaan itu! Tekad Mona dalam hati (Alya, 2016: 15).

"Apa pun yang terjadi, aku harus memasukkan bola ini dan mendapatkan skor tertinggi... aku tidak peduli bola ini akan masuk atau tidak...yang penting aku sudah berusahaa...!" Mona melempar bola dari jarak jauh. Sejenak, semua orang memerhatikan tingkahnya itu. Mata mereka seolah lekat sekali dan sulit melepas aksi Mona. 
"BERHASIL...!" Pekik Mona tak percaya.

"Priiit...!" peluit tanda usai perlombaan basket ditiup (Alya, 2016: 98).

Rasanya, ini seperti mimpi bagi Mona. "Hidup Mona...!"sorak teman-teman Mona. Mona tak pernah sesenang ini. Apalagi di atas sana, Lisa beteriak-terak untuknya (Alya, 2016: 99).

Pada perkembangan terdapat konflik antara positif dan negatif selalu ada sepanjang hayat yang dapat membuat kepribadian menjadi hidup. Kepribadian itu berawal dari didikan keluarga karena keluargalah yang berperan penting dalam memberikan didikan sehingga dapat membentuk kepribadian anak. Tokoh Mona dan Lisa mempunyai sifat yang hampir sama yakni bersahabat dengan siapa saja, cerdas dan tidak pernah memandang seseorang dengan remeh, mereka berdua meski berpisah rumah namun tetap saling menyayangi sebagai saudara kembar. Dibalik sifat yang baik mereka mempunyai sifat yang kurang baik yakni mereka berdua merasa kurang puas ketika Mona diasuh oleh Mom dan Lisa di asuh oleh Dad, mereka beranggapan belum mendapatkan kasih sayang dan didikan yang berbeda akan hal itu mereka berdua mempuyai keinginan mendapatkan didikan yang seimbang dari kedua orangtuanya. Mona yang diasuh oleh Mom dengan didikan di manja sesuai denga sikap perempuan yang penuh kelembutan mempunyai kepribadian kurang mempunyai sikap pemberani sedangkan Lisa yang diasuh oleh Dad di didik dengan keras dan tegas sesuai dengan kepribadian laki-laki sehingga mempunyai kepribadian yang pemberani. Akan adanya konflik positif dan negatif dari sifat dan dipengaruhi oleh didikan membuat mereka 
mempunyai kepribadian yang menonjol berbeda. Bahwa Mona lebih mempunyai sifat yang lembut, kurang berani menghadapi permasalahan sedangkan Lisa mempunyai sifat yang pemberani meski demikian mereka mempunyai sikap baik yang telah tumbuh pada diri mereka. Bukti kutipan sebagai berikut:

"Kau tahu, selama aku tinggal bersama Dad, aku rindu sekali pada kalian berdua. Dad memperlakukanku dengan keras dan seperti tanpa rasa sayang. Beliau tidak mau aku cengeng atau menyusahkannya. Dad memang keras dan bijaksana. Aku selalu merindukan kasih sayang seorang Ibu," kata Lisa.

"Lisa, justru aku yang selalu rindu pada Dad. Aku ingin merasakan kebijakan seorang ayah sehingga aku tak terus-terus dimanjakan," sambung Mona (Alya, 2016: 106)

Sifat yang menunjukkan Mona lebih mempunyai sifat yang lembut terlihat ketika Mona mendapatkan tantangan dari Tivanna dan Lolyta, Mona hanya bisa diam dan menyanggupi apa tantangan dari Tivanna dan Lolytta tanpa membalas perbuatan kasar mereka yang sudah dilakukannya namun Lisa sewaktu menyamar menjadi Mona dan mendapatkan hinaan dari Tivanna dan Lolytta. Lisa pun tak segan-segan untuk membalas perbuatan kedua temannya yang sudah berbuat tidak baik terhadap dirinya, Mona dan sahabat dekat Mona di kelas. Bukti kutipan sebagai berikut:

"lya...nggak mungkin banget kamu yang terpilih diantara semua bidang itu... kau hanya mimpi! Tambah Lolyta.

"Aku pikir, tak ada salahnya memilih, dan aku memang berhak untuk memilih. Lihat saja nanti!" tanggap Mona. 
"Oke, kami akan menantikan hari itu!" Tivanna memandangi Mona dengan tajam, lalu meninggalkan kelas. Lolyta dengan sengaja menyenggol bahu Mona, setelah itu dia menyusul Tivanna keluar kelas (Alya, 2016: 10).

Tivanna mendorong Lisa hingga jatuh terjerembap. Lisa meringis. Tangannya terasa sakit dan lecet.

"Hahaha... segitu saja sudah jatuh. Dasar Mona payah, semuanya juga tahu. Kini kau sudah sembuh, tetapi aku tak akan membiarkanmu menjadi kapten tim basket lagi. Aku akan mencoba merebut posisimu, Mona! Anak cengeng sepertimu.. cuih, tidak pantas benar menjadi kapten tim basket!"

Lisa melotot.dia benar-benar arah mendengar perkataan Tivanna.

"kau menyebalkan, jelek... huaaa...!" Lisa bangkit, kemudian dengan kesalnya mendorong Tivanna hingga menabrak tembok di belakangnya.

"Awh!" pekik Tivanna

"Jangan sekali-kali menghina seperti itu lagi! Kau tidakpantas berkata seperti itu karena kau sendiri tidak jauh dari kata-kata yang tadi kau ucapkan itu. Kau itu sama saja dengan apa yang kau katakan tadi..." jerit Lisa. Dia tidak bisa menahan amarahnya. Dia kesal karena telah didorong dan jatuh, dan yang lebih penting, dia tidak bisa terima jika saudara kembarnya sendiri dimaki-maki.

"Menyeramkan! Mona...," Tivanna tersenyum masam.

"Kenapa, ada yang salah denganku?" Lisa mengatur napasnya.

"Jangan kurang ajar kepada temanku!" Lolyta menampar Lisa dengan keras. PRAK...

"Awh, aih, menyebalkan! Hh, sakit!" Lisa memegang pipinya yang kini memerah.

"kalian berdua kurang ajar... huweee... rasakan ini! Aku marah... aku tidak terima... kyaaa!" teriak Lisa sambil mendorong Lolyta hingga jatuh, kemudian menjambak-jambak rambut Lolyta hingga acak-acakan (Alya, 2016: 58-60) 
Selain hal itu dapat dilihat ketika Dad sedang terbaring sakit Mona langsung memeluk Dad dan sifat Mona yang kurang pemberani dibanding Lisa bisa terlihat ketika Lisa berani menghentikan pertengkaran oragtuanya meski Lisa harus menerima bentakan dari kedua orangtuanya sedangkan Mona yang melihat kondisi itu hanya bisa berlari dengan perasaan sedih, berlalu begitu saja meninggalkan ruangan diamana Dad di rawat. Bukti kutipan sebagai berikut:

"Kau?" Dad memandang Mona dengan penuh rasa heran.

"Dad..." sambil menahan air matanya, Mona memeluk Dad (Alya, 2016: 107) "Lelaki memang menyebalkan!" "wanita sungguh menjengkelkan!" "DAD, MOM, HENTIKAN...! jerit Lisa sudah tidak tahan lagi. "diam!" UJAR Dad dan Mom serentak.

"kenapa kau membentak Lisa?"

"Kau sendiri?

"Aku ibunya da aku berhak membentaknya!"

"Aku ayahnya yang selalu merawatnya dan aku megetahui watak Lisa!"

"yang melahirkannya lebih tahu!"

"yang merawatnyalah yang lebih mengetahui wataknya!"

"Dad... Mom, hentikan! Hiks... "Mona berlari meninggalkan ruangan (Alya, 2016: 107-108)

Akan analisis tersebut, dapat dikatakan kemampuan anak meski saudara kandung pun mempunyai sifat yang berbeda bergantung sesuai didikan semenjak kecil dan pencapaian keberhasilan anak juga sangat 
dipengaruhi oleh pengalaman masa lalu, sekarang dan harapan di masa depannya.

\section{SIMPULAN}

Akan adanya karya sastra anak dapat digunakan sebagai pengetahuan oang dewasa maupun orangtua dalam memahami karakter anak-anak dan dapat memberikan pengetahuan kepada anak sesuai dengan usianya. Pada KKPK yang berjudul Monalisa kajian Psikologi kepribadian Norman H. Erikson dapat dikatakan tokoh Mona dan Lisa pada masa perkembangan kerajinan dan Inferioritas lebih mementingkan kepada pelajaran sekolah dan Keterampilan ego yang dimiliki oleh Mona dan Lisa adalah kompetensi dalam ekstrakulikuler basket. Ego yang diperoleh dipengaruhi dari pengalaman masa lalu, sekarang dan masa yang akan datang. Dari hasil analisis, kepribadian anak yang pemberani maupun pendiam, dapat dikatakan sangat dipengaruhi cara mendidik orangtua kepada anaknya.

\section{DAFTAR RUJUKAN}

Alwisol. 2016. Psikologi Kepribadian. Malang: UMM Press.

Karin. 2012. Psikologi Norman. Ha. Erikson. (Online) Blog, https://kharinblog.wordpress.com/2012/11/24/tahaptahap-perkembangan-psikososial-erik-erikson/ (diunduh pada 31 Oktober 2016). 
Neva Atika Sari, Perkembangan Anak pada...(hal. 186-201)

Nurgiyantoro, Burhan. 2004. Sastra Anak: Persoalan Genre.

(Online Jurnal, https://journal.ugm.ac.id (diunduh 21

Desember 2016)

Ratna, Nyoman Kutha. 2004. Teori, Metode dan teknik penelitian sastra. Yogyakarta : Pustaka Pelajar.

Rokib, Mohammad. 2015. "Reading Popular Islamic Literature: Continuity and Change In Indonesian Literature," in Heritage of Nusantara: International Journal of Religious Literature and Heritage, vol. 4, no. 2 (2015)

Rokib, Mohammad. 2016. “Negosiasi Islam dan Budaya Lokal pada Terjemahan Novel Kisah Seribu Satu Malam: Sebuah Kajian Parateks," dalam Ibda: Jurnal Kebudayaan Islam, vol. 14, no. 1 (2016)

Sugiarti. 2013. Kajian Sastra Anak "Kecil-kecil Punya Karya The Evergreen" Karya Nirsina Hanifah dalam Perspektif Pendidikan Karakter. (Online) Jurnal, http://ejournal.umm.ac.id/ (diunduh tahun 2016). 